\title{
STATUS OF WATER SUPPLY IN PARTS OF UMUAHIA SOUTH LOCAL GOVERNMENT AREA, ABIA STATE, NIGERIA: A LOOK AT ALTERNATIVES.
}

\author{
Ngah, S. A. ${ }^{1 *}$ and Ekpebegh, U. $\mathbf{N}^{2}$
}

*Corresponding Author:

Email: ngahsab@yahoo.com

\begin{abstract}
: -
The study investigated the water supply sources in Old Umuahia semi-urban district in Abia State, Nigeria. Emphasis was on the quality and quantity of available water sources. Some socio-economic considerations such as family sizes, proximity of source, quality and quantity of water actually used per day as compared with quantity required per day were all evaluated. Water supply shortfall was hence evaluated and quantified. Different sources of water in use were evaluated. They include motorized boreholes, Springs, Streams, commercial water vendors and harvested rainwater. The study showed that the majority of residents had bread winners who were civil servants (48\%) with an average family size of 5-8 people. Most people practice conjunctive water use of water combining more than one source with comparative advantages. $89 \%$ of the people depend on water boreholes for their drinking water supplies. Available hydrogeological data from the area were reviewed. The area was found to be underlain by a prolific aquifer capable of sustainably supplying the area. Water samples were collected from the different water sources and analysed for concentration of key physico-chemical parameters such as $\mathrm{pH}$, Dissolved Oxygen, conductivity, turbidity, total dissolved solids, total hardness, chloride, salinity, total alkalinity, copper, iron, manganese, sulphate, chromium, colour and zinc. The results were compared with World Health Organisation (WHO) standards for domestic water supply. From the results, water in the area was found to be acidic with $\mathrm{pH}$ values ranging from 4.9 to 5.15 (mean value, 5.02). All the other physico-chemical parameters showed values that plot within the limit of acceptability of WHO standards except for two boreholes sources, two streams sources and samples from the commercial water vendors whose water samples indicated serious bacteriological contamination. Supplies from groundwater sources is of highest quality. Since the area is underlain by aquifers with excellent water yielding properties, the study recommended the development of water supply in the area mainly from groundwater sources. This will require additional hydrogeological studies to determine the number, location and depths of new boreholes to serve the domestic water demands of the inhabitants of the area. Existing four boreholes are grossly inadequate to meet and sustain the domestic water needs of about 8000 people who presently inhabit the area. Similarly, people should be discouraged from using the water from commercial water vendors for domestic purposes. This will drastically reduce the incidence of water-borne diseases in the area.
\end{abstract}

Keywords: water supply, old Umuahia, status, alternatives

\section{(우 (\$) (1)}




\section{INTRODUCTION.}

Old Umuahia is a semi -urban district in Umuahia South Local Government Area of Abia State in Eastern Nigeria. It is populated by approximately 8000 people mainly farmers and civil servants. Like Old Umuahia, over $75 \%$ of the population of Abia State live in rural communities where modern water supply facilities are lacking. The inhabitants depend on traditional sources that are generally of questionable quality, insufficient in quantity and often liable to seasonal failures. As a result, water borne diseases like typhoid fever, dysentery, diarrhea and hepatitis remain a regular threat in the rural areas. Sources of adequate water to meet the water needs of the people of Old Umuahia is a major challange. This study was carried out with the following objectives: (a) identify the sources of water supply in Old Umuahia semiurban area, (b) evaluate the water supply alternatives in the area in terms of quality and quantity and (c) assess the suitability of any source for development of a sustainable water supply scheme for Old Umuahia.

\section{DESCRIPTION OF THE STUDY AREA}

The study area is Old Umuahia District, Abia State, Nigeria.The Umuahia and Ikwuano areas of South-Easthern Nigeria are located within the Kwa Ibo River watershed. The watershed is located between longitudes $5^{\circ} 19^{\prime}$ and $5^{\circ} 30^{\prime} \mathrm{N}$ and between latitudes $7^{0} 28^{\prime}$ and $7^{0} 35^{\prime} \mathrm{E}$. It is drained by the Kwa Ibo River, which rises near Umuahia and flows in a southeasterly direction. Its main tributary is the Anya River and it flows across the premises of the Micheal Okpara University and the National Root Crops Research Institute both in Umudike, (Igbokwe et al 2006). Old Umuahia is located within $5^{\circ} 25^{\prime}$ and $5^{0} 30^{\prime} \mathrm{N}$ longitudes and $7^{0} 28^{\prime}$ and $7^{\circ} 30^{\prime} \mathrm{E}$ latitudes. The area stands on altitude of about $151 \mathrm{~m}$ and is made up the following sub districts: Umueledi, Umuovo, Umuecheokwu, Umuobutu, Umuezeala, Amuzuta, Okwu, (figure 1).

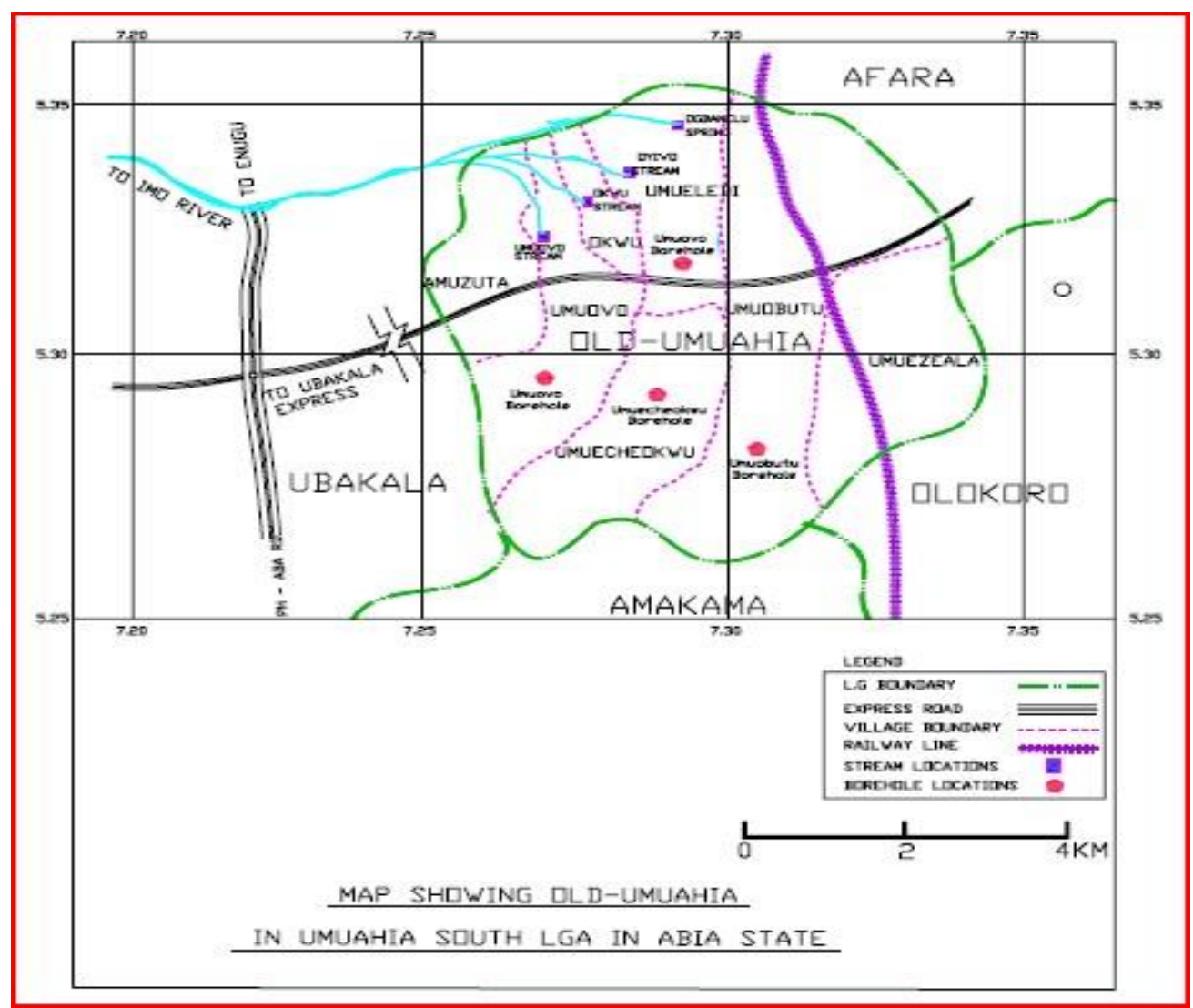

Figure 1. Map of Old Umuahia showing locations of boreholes and streams.

\section{GEOLOGY, HYDROGEOLOGY AND CLIMATE.}

The oldest formation in the area is the impervious Imo shale of Palaeocene age. The Imo shale is overlain by the Bende -Ameki Formation of Eocene to Oligocene age which in turn is overlain by the Benin Formation. The Bende-Ameki Formation consists of medium to coarse - grained white sandstone, which may contain pebbles, gray-green sandstone, blueish calcareous silt, with mottled clays and thin limestone, (Uma and Egboka 1988). There is also considerable lateral variation in lithogy. The lower part of the formation consists of fine - coarse - grained lenses of sandstones with abundant calcareous shales and thin shelly limestone. The Benin Formation, Miocene to Recent in age consists mostly of mediumto coarse-grained, pebbly, moderately sorted sands with clay local lenses of poorly cemented sands and clay (Ukandu et al, 2011). Coastal Plain Sands dip southward (Igboekwe et al, 2006) and is shallow in Umudike where the expected thickness is about 200m (Ebillah-Salmon \& Partners, 1994)

There are two marked seasons in the year namely rainy (March-October) and dry season

(November to February) The hottest months are January to March with mean monthly temperature of $27^{\circ} \mathrm{C}$. The relative humidity is usually high throughout the year, reaching a maximum of $90 \%$ during the rainy season, (Ile 2003, Ile and Udoinyang 2013). 


\section{EXISTING WATER SUPPLY SOURCES}

Historically, people of Old Umuahia area have relly on surface water sources from streams and ponds. Notable amongst the streams are the Oyivo, Iyi Okwu and Iyi Umuovu Streams, which are not perennial and the Ogbanelu Spring which is very difficult to access due to its difficult terrain resulting from gully erosion. Boreholes and rainwater sources have had limited successes in the past.these sources are augumented with supplies from commercial water vendors. There is no structured system of water supply.

\section{(a) Ogbanelu Spring}

The Ogbanelu Spring is a source of 'clean' water and has been a major source of drinking water for the local community for a long time. Over the years drawing water from this source has become increasingly difficult. This is because the few natural spring water sources are hard to access due to difficult terrain; since the sites are often affected by severe gully erosion. Again the quantity is inadequate to meet the domestic and industrial demands.

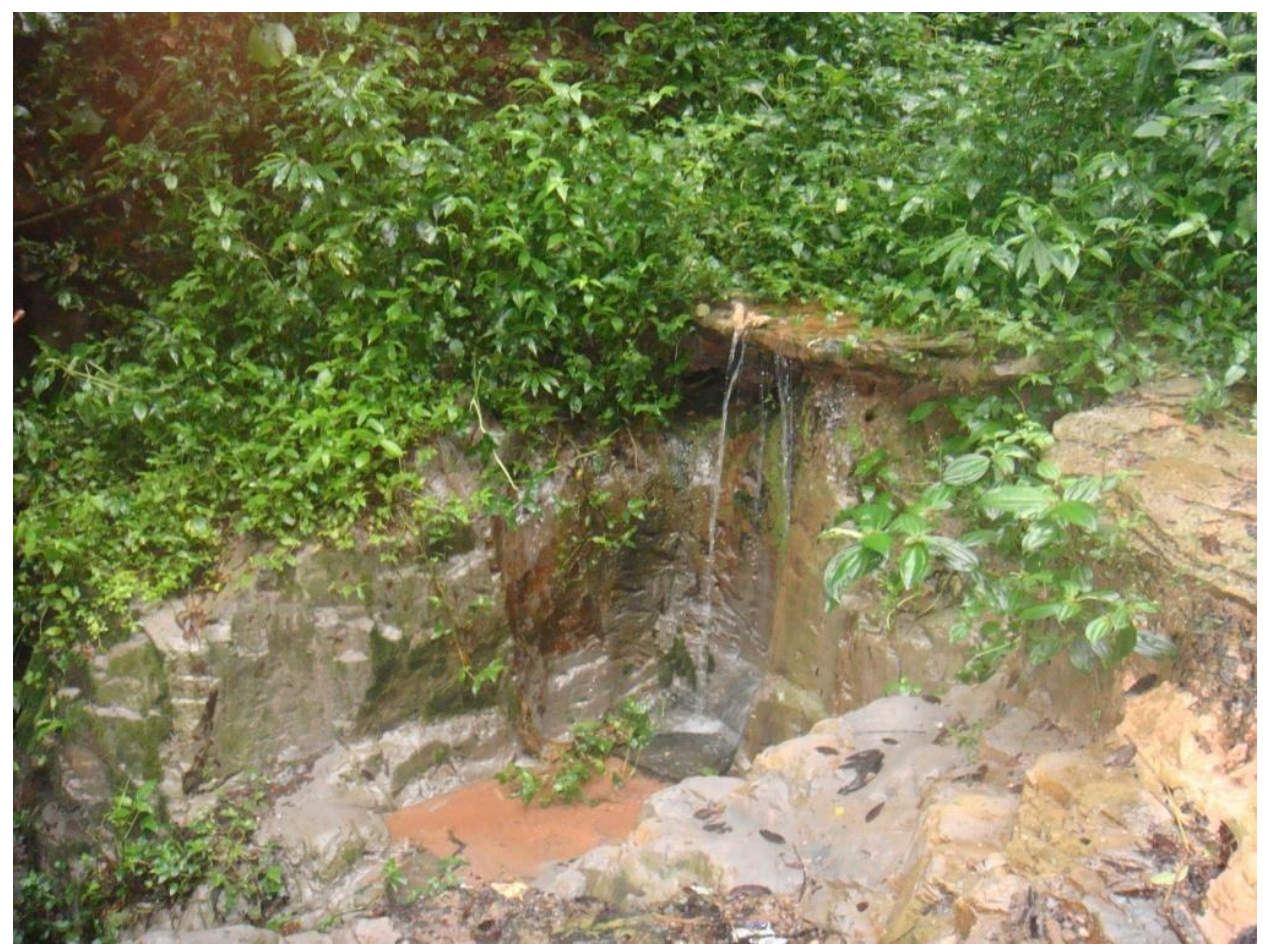

Figure 2. Ogbanelu Spring in Old Umuahia showing Bushy Surroundings

\section{(b) Commercial Water Vendors (Tanker and Jerrycans)}

People who live far away from the few existing boreholes rely on commercial water vendors who supply water using tankers. A number of concerns are associated with water supplied to consumers by water vendors. These include quantity and quality of water supplied.

\section{(c) Streams (Oyivo, Iyi Umuovo and Iyi Okwu)}

These surface water bodies have been a major source of water in Old Umuahia over time. Presently, they unable to adequately support the community due to silting up of the streams, shrubs overgrowth and erosion of the access. The quality of the water is also questionable. 


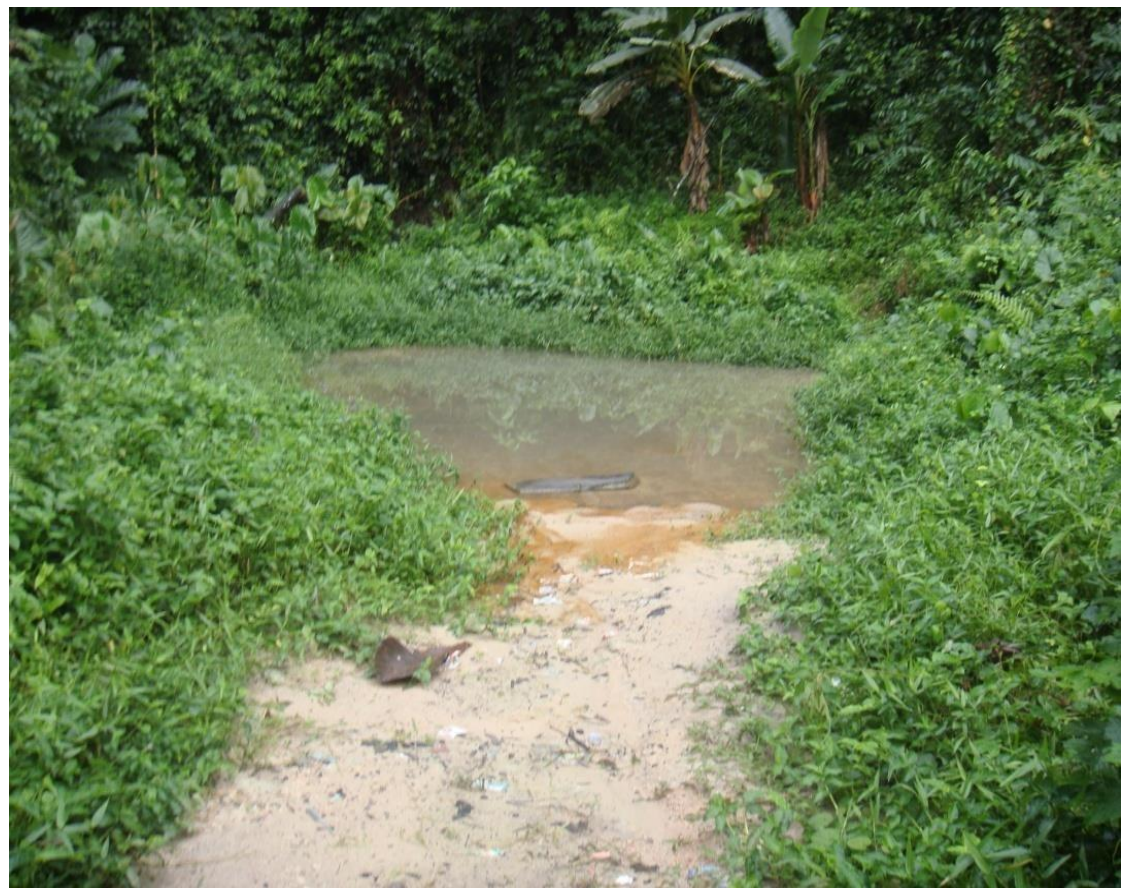

Figure 3. Oyivo Stream in Old Umuahia showing shallow nature and bushy surroundings

\section{(d) Rain Water Harvesting:}

This is seasonal as there are limited rains during the dry season. The quality of water collected also depends on the type of roofing sheets used in buildings and the collection/storage.

\section{(e) Private Water Boreholes:}

This is the most popular source of water for domestic and industrial purposes in Old Umuahia. Private individuals sink boreholes in their compounds to provide water for their needs and also sell some to their neighbours.

\section{MATERIALS AND METHODS \\ Data Collection}

The data for this study were obtained from field sampling and analysis and review of previous relevant works.

\section{a. Water Sampling}

Water samples were collected from the identified sources of water in Old Umuahia. The samples were collected in 2litres plastic sampling containers and transported in ice chests/coolers. These were taken to the laboratory for quality analysis. Sampling was done using 'thief can' into 2-litres plastic sampling containers. The samles were properly labeled. Insitu measuremnets were made of $\mathrm{pH}$, Dissolve Oxygen (DO), Temperature, Conductivity, salinity using appropriate meters and the samples were taken to the laboratory for physico-chemical analysis using standard methods.

Data analysis involved comparing obtained water quality parameters with international standards.Questionnaires were also administered to the local inhabitants to assess their perception of the water supply situation (sources, quantity and quality) in the area. 1800 Questionnaires were issued out of which 1700 responded.

\section{RESULTS AND DISCUSSIONS}

(A) Hydrogeological Data and Groundwater Reserves.

Old Umuahia is underlain be a thick sequence of sediments comprising clay, sandy clay, white to medium grain sand and fine sand. The sand bodies form discontinuous aquifers consisting of fine to coarse grained sands with variable permeability and clay intercalations. Depth to water table varies averaging $90 \mathrm{~m}$. Groundwater is encountered at relatively shallower levels to the west Imo River. This suggests that the aquifer at the western part of the study area has an effluent relationship with Imo River from which it may be receiving sizeable recharge. Depths to water levels are more in the East beyond the Aba - Umuahia Expressway. Applying de Marsily (1986) model and using an effective porosity of $25 \%$ for the area (Johnson 1967); the estimated groundwater reserve for the area was calculated as $2.70 \times 10^{9} \mathrm{~m}^{3}$. Old Umuahia falls into Imo River Basin. The basin receives a large amount of recharge; estimated at 2.5 billion $\mathrm{m}^{3}$ per annum, coming mainly from direct infiltration of precipitation from an area with average annual rainfall of about $2000 \mathrm{~mm}$ (Onwuegbuche, 1993). This recharge is considered enough to adequately replenish the groundwater withdrawals without any undesirable consequences. At present only four boreholes deliver groundwater to the area. The hydraulic conductivity varies between 8.5 and $8.65 \mathrm{~m} / \mathrm{d}$ while the transmissivity values are in the order of $2550 \mathrm{~m}^{2} / \mathrm{d}$. The hydraulic parameters are indicative of aquifer with excellent water yielding properties. More boreholes can be accommodated by the aquifer to optimize their use and enhance on the quantum of raw groundwater delivered. 
(b) Socioeconomic considerations on available water sources.

Figures 4-14 show the statistics of responses of the inhabitants to questions on water supply situation.

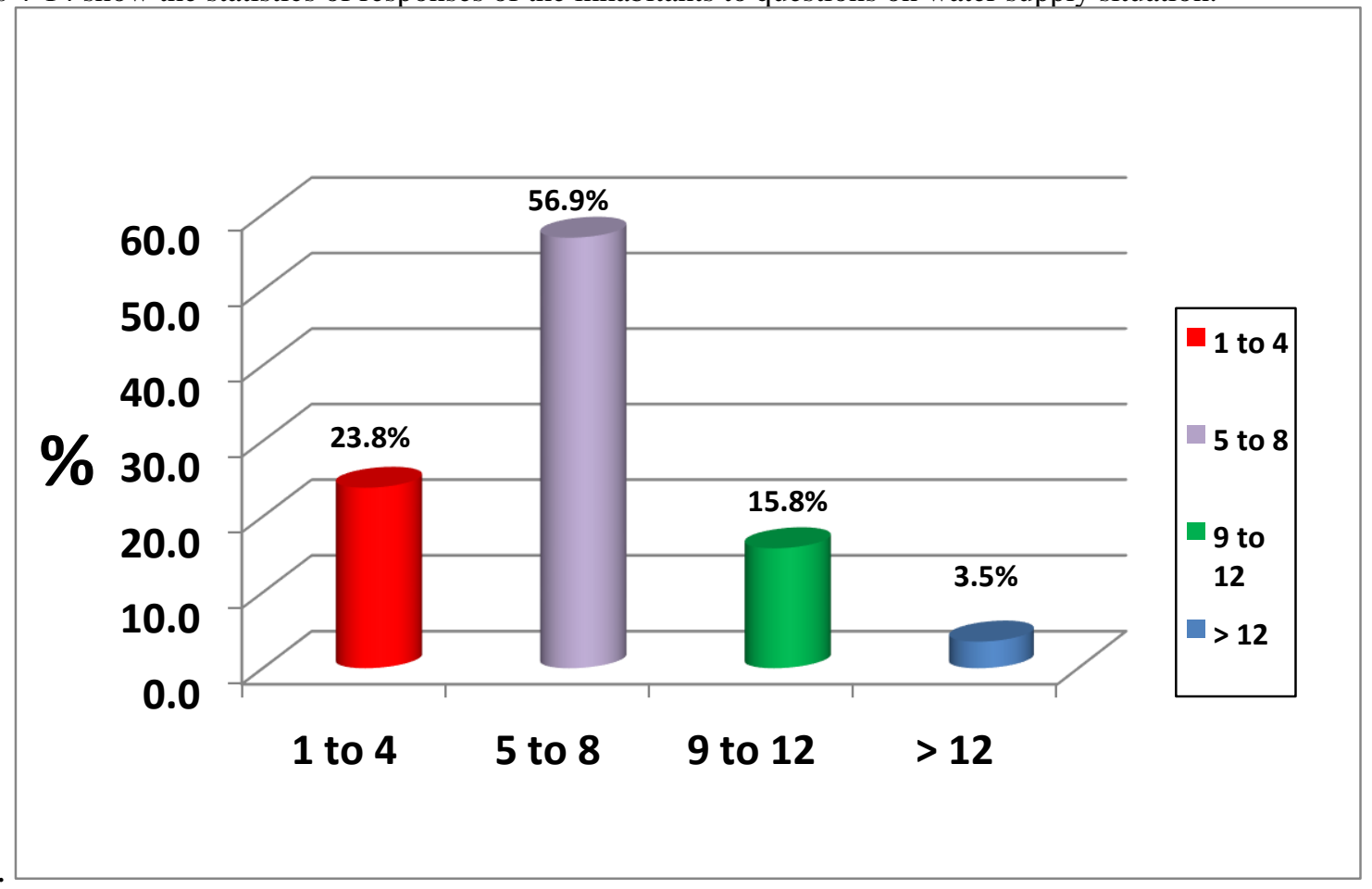

Figure 4. Average number of people in family

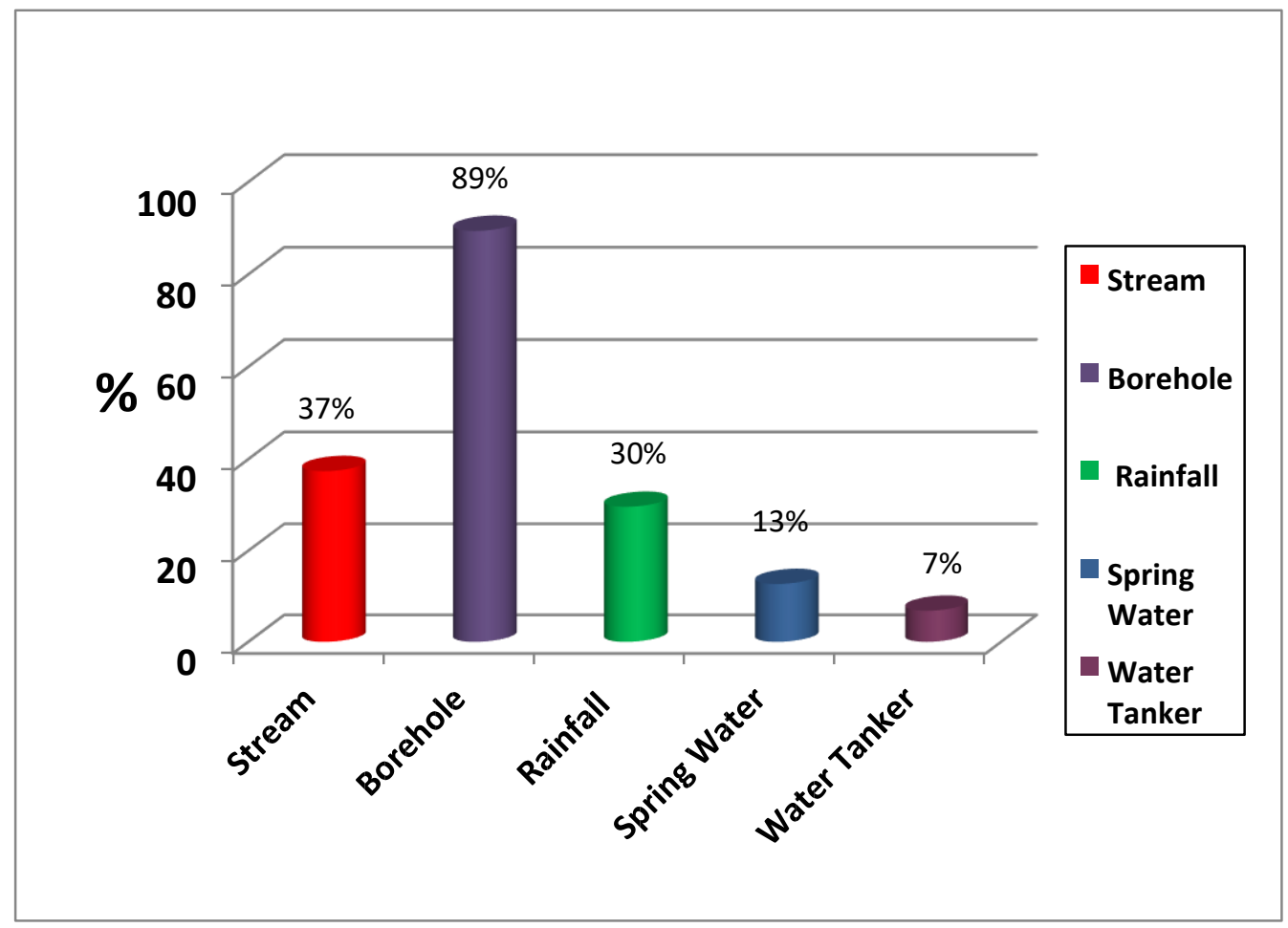

Figure 5. Sources of water supply 


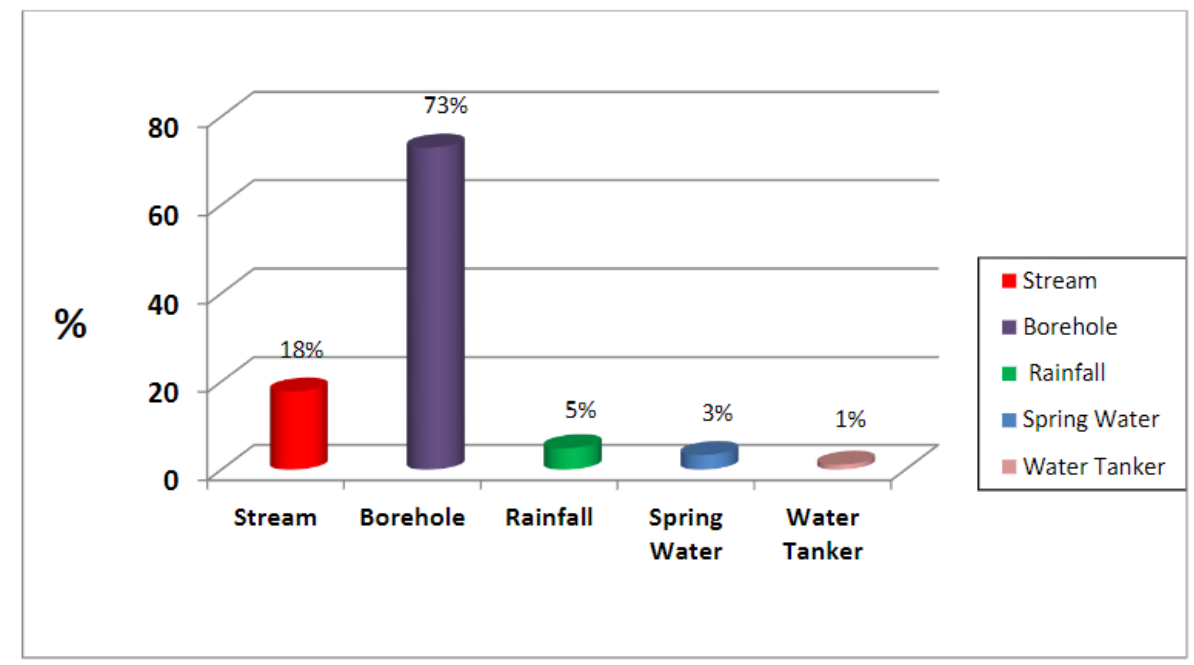

Figure 6. Closest source of water

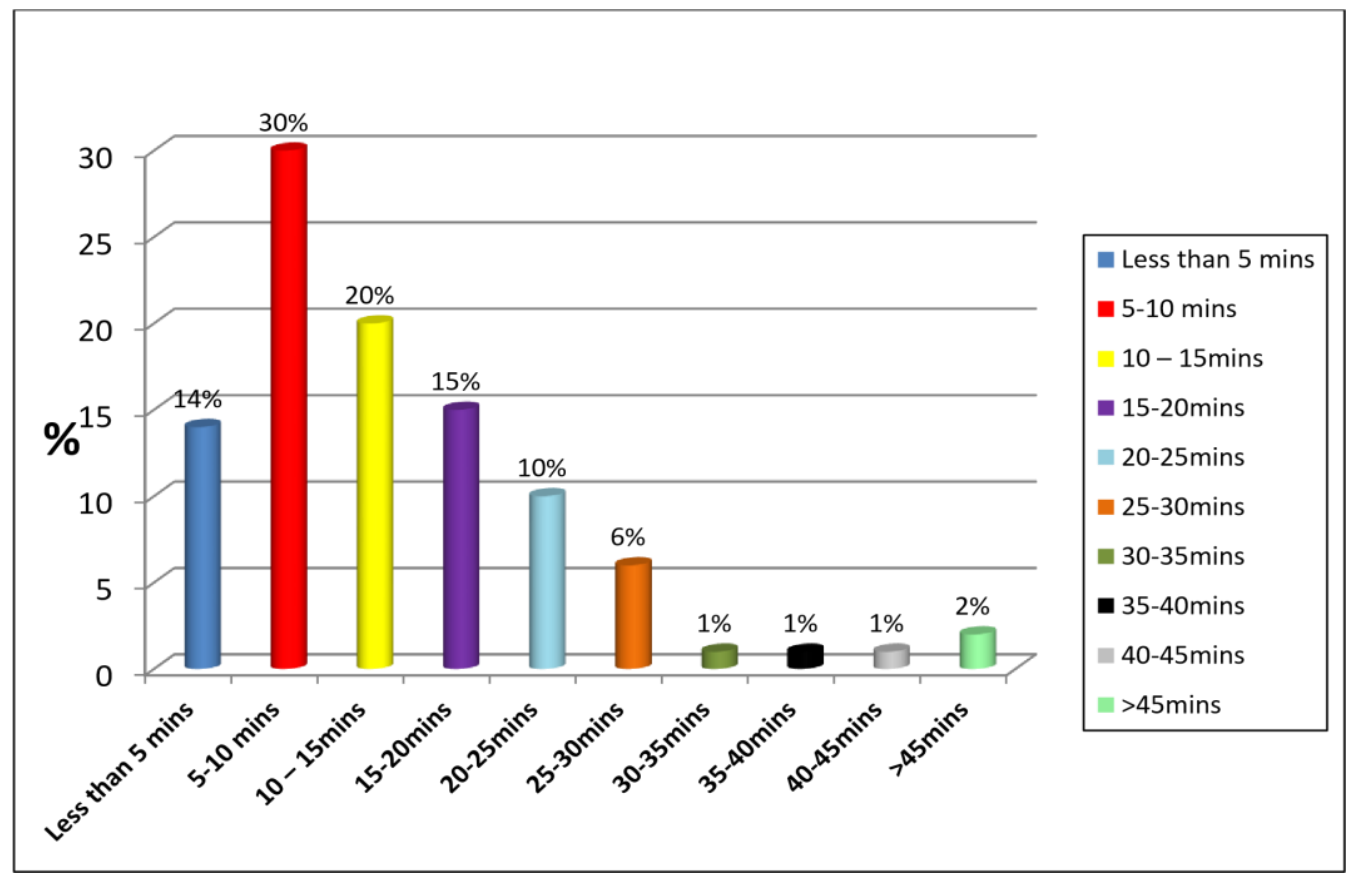

Figure 7. Proximity of source of water

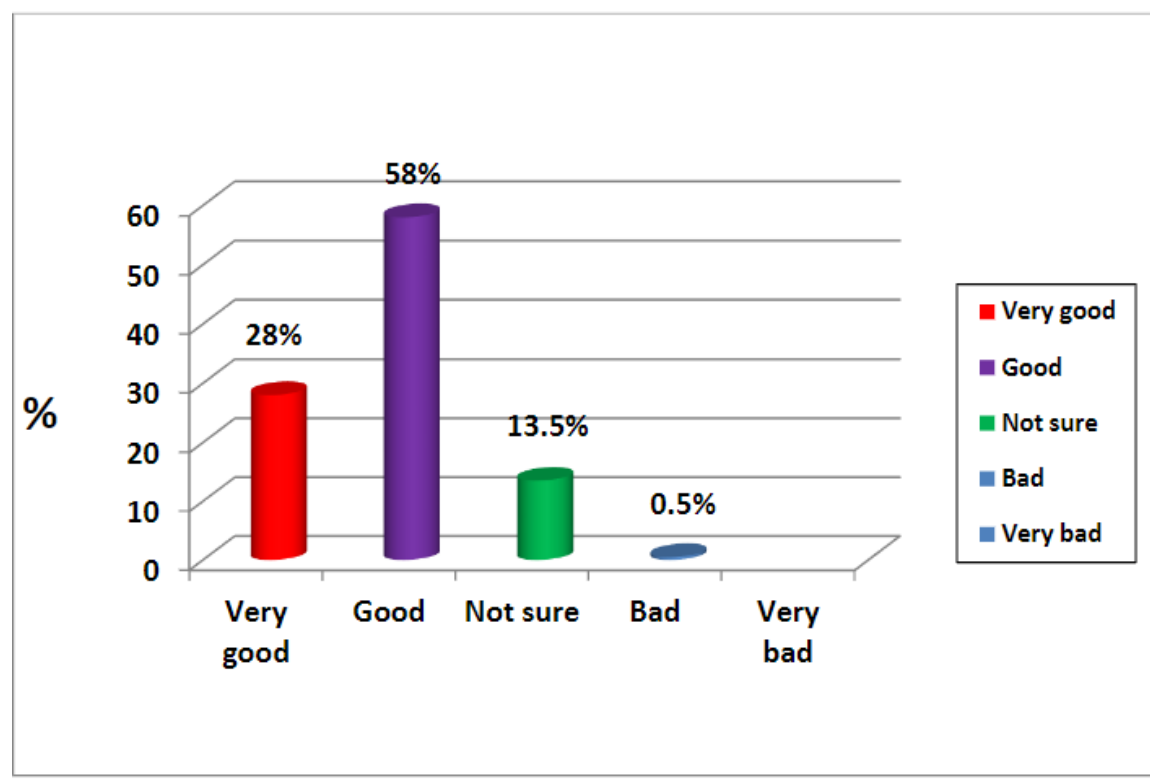

Figure 8. Quality of water from nearest borehole 


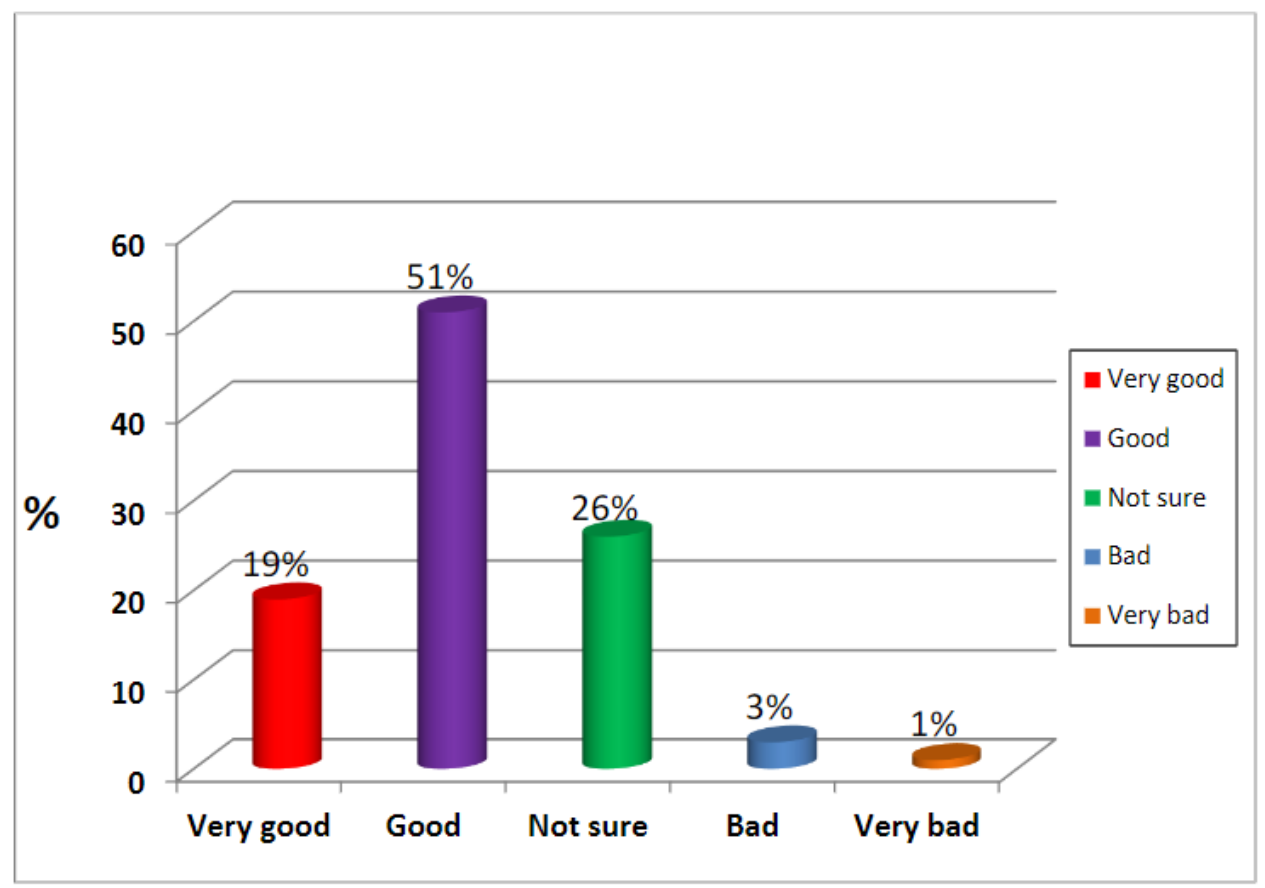

Figure 9. Quality of water from stream

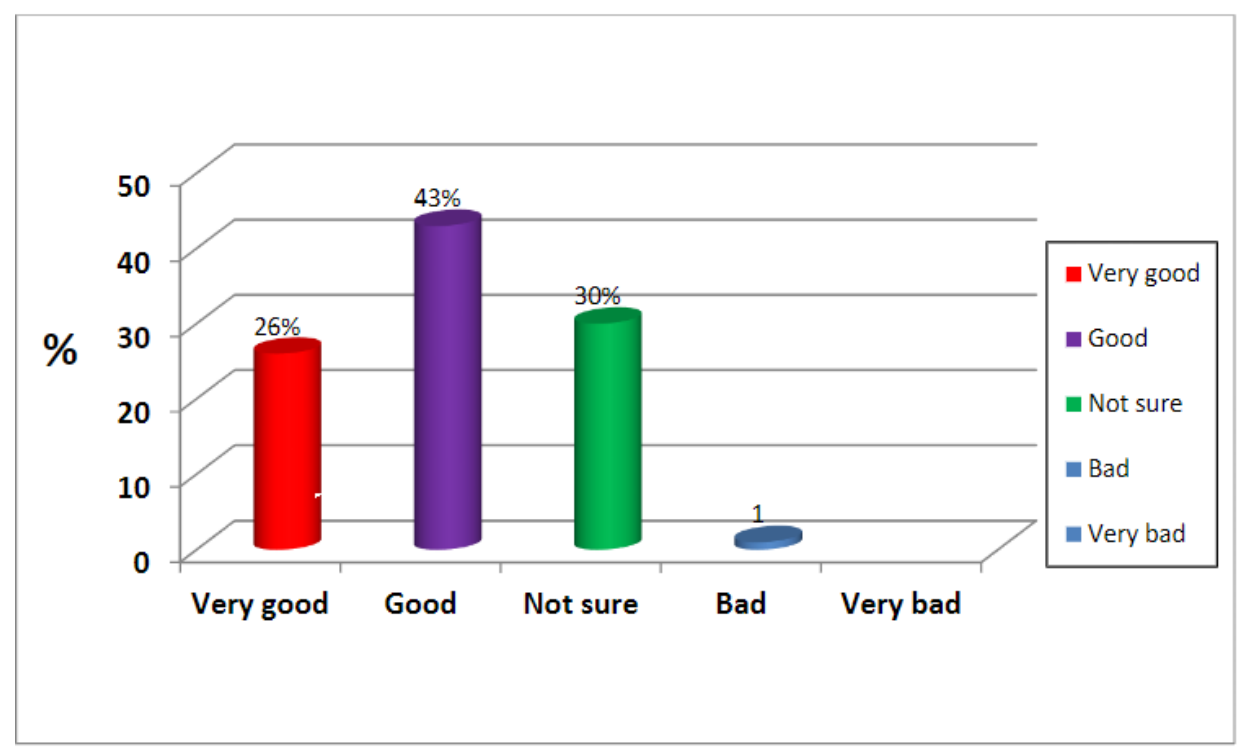

Figure 10. Quality of water from spring 


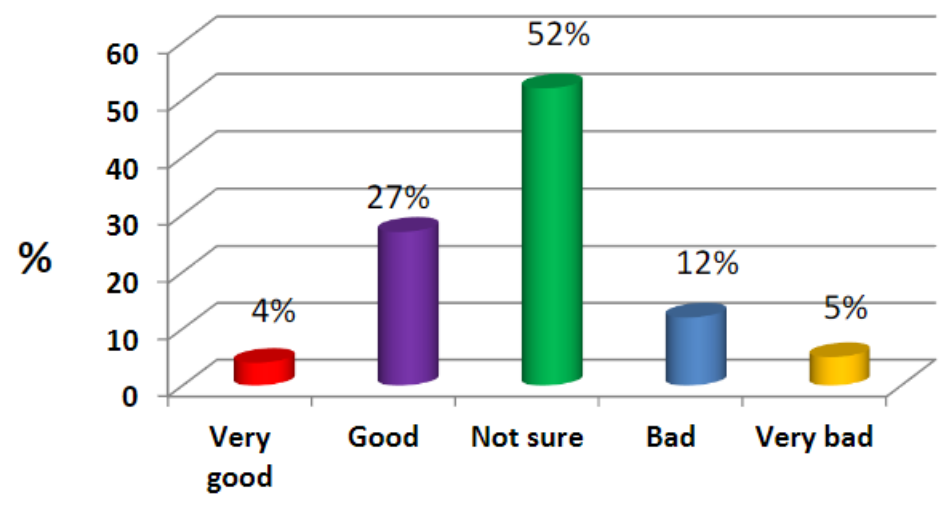

Figure 11. Quality of water from tanker

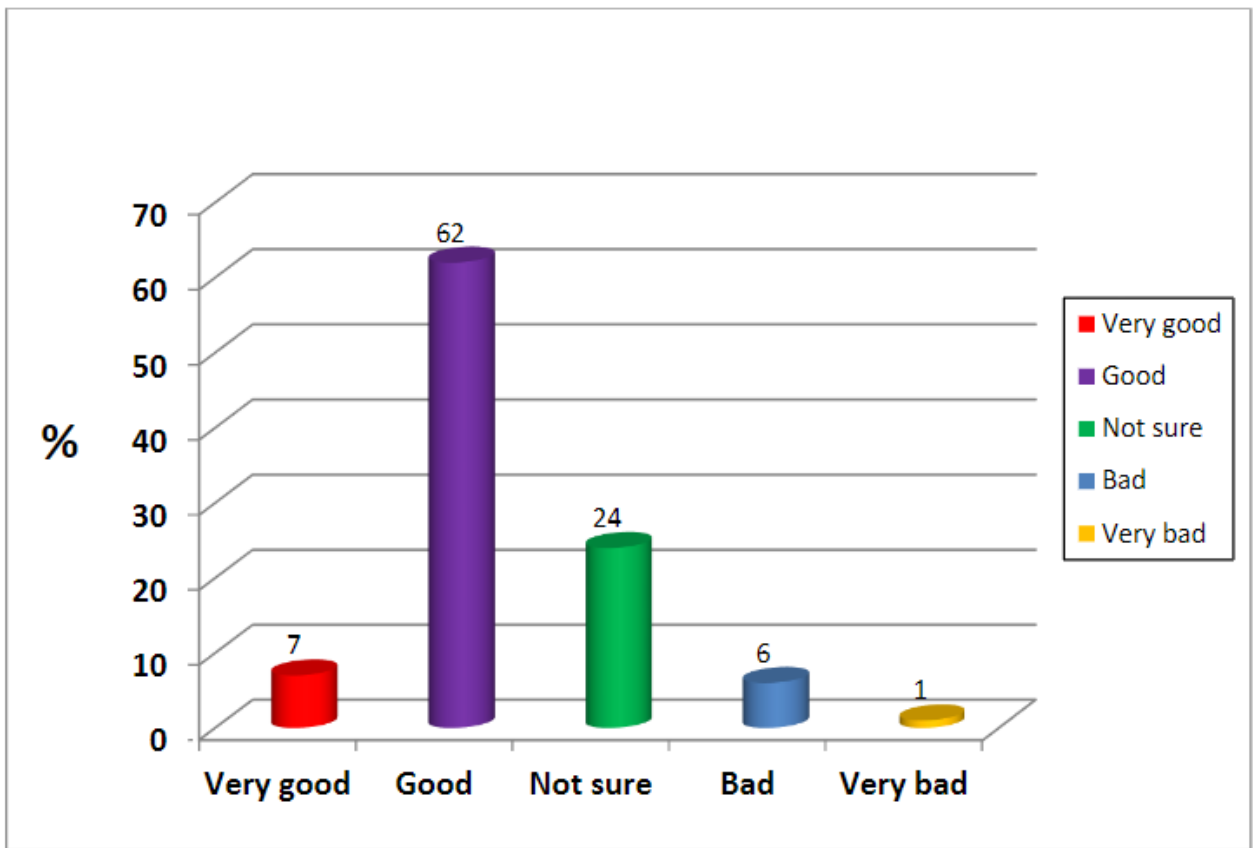

Figure 12. Quality of rain water

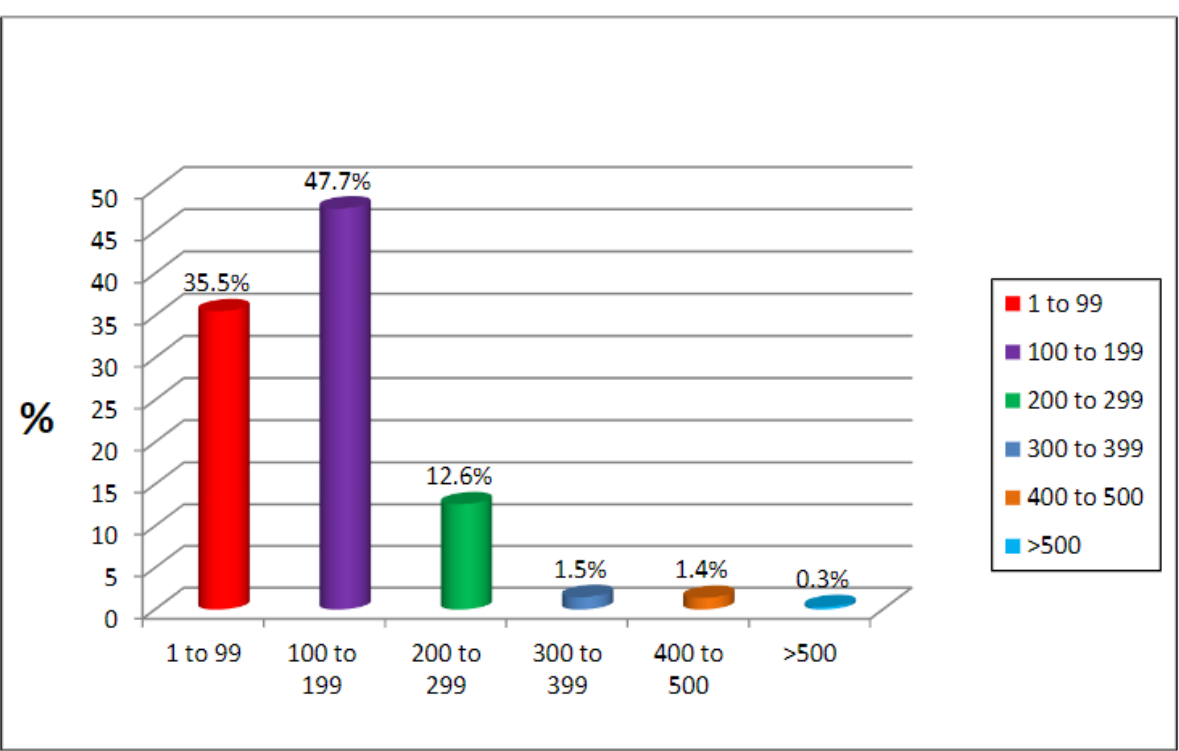

Figure 13. Water needs per household per day 


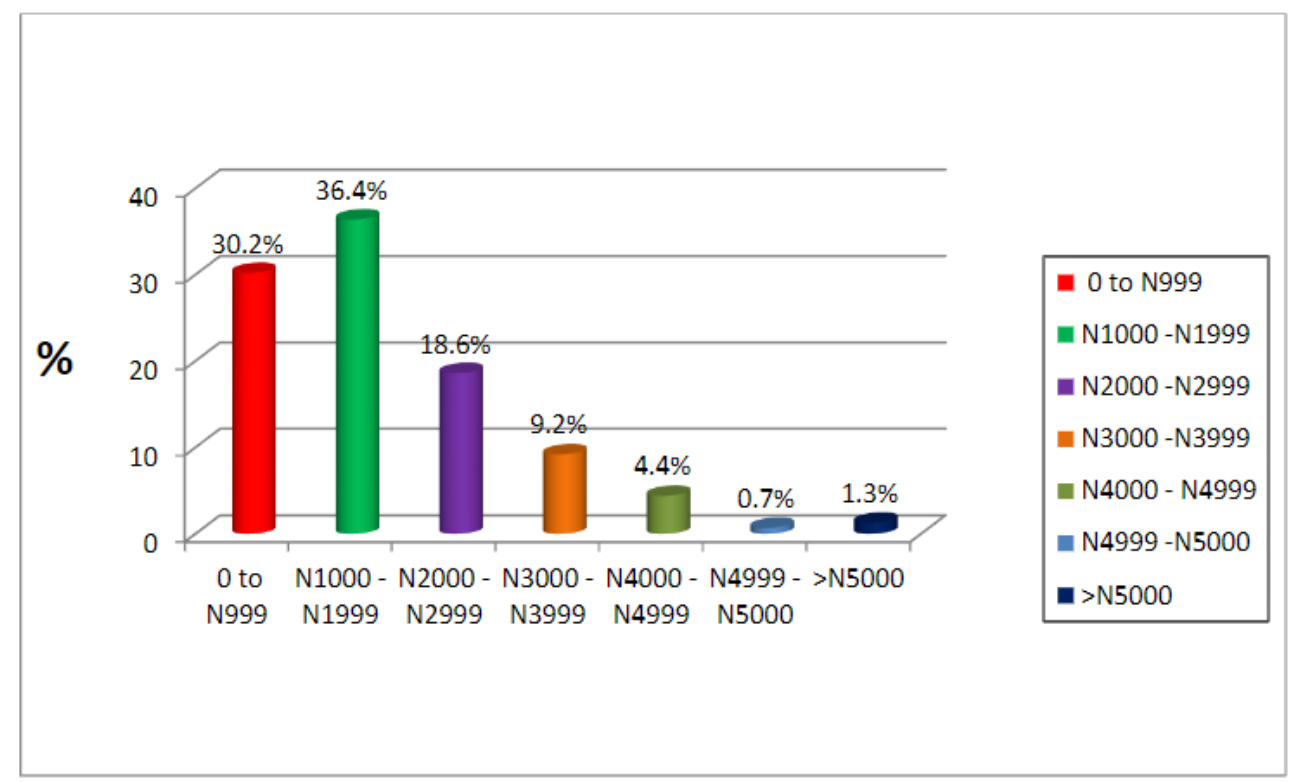

Figure 14. Money spent on water per household per month.

The statistics show that the dominant family size in the area is 5-8people. Figure 15 shows the hierarchy of water requirements for the third world countries with 70 litres as the per capita water requirement per day. The average quantity of water available for a household of 5-8 persons (100199 1) is far less than the needed 350 - 5601, (figures 4,13 and 15). With the national per capita water at 120 litres per day, it is obvious that most people in the study area do not have the necessary quantity of water for their daily needs. It further shows the order of patronage of the various sources of water supply as borehole $>$ stream $>$ rain water $>$ spring $>$ commercial water vendor, (figure 5). Analysis of proximity to water source shows that most people live between 5-30mins trekking distance from a water source, an average of 10-60minutes for a round journey, (figure 7). The perception of the inhabitants on quality of water shows a very high confidence level on stream, spring and borehole sources. Water from rainfall and commercial water vendors have the least acceptance of quality, (figures 8-12). These opinions about water quality are purely subjective since they are not based on laboratory analysis in order to arrive at rational conclusions. It is further revealed that about $15 \%$ of the population spent more than $\mathrm{N} 3,000.00$ monthly on water. With a national monthly minimum wage of N18,000.00, water is therefore not affordable to a good number of families.

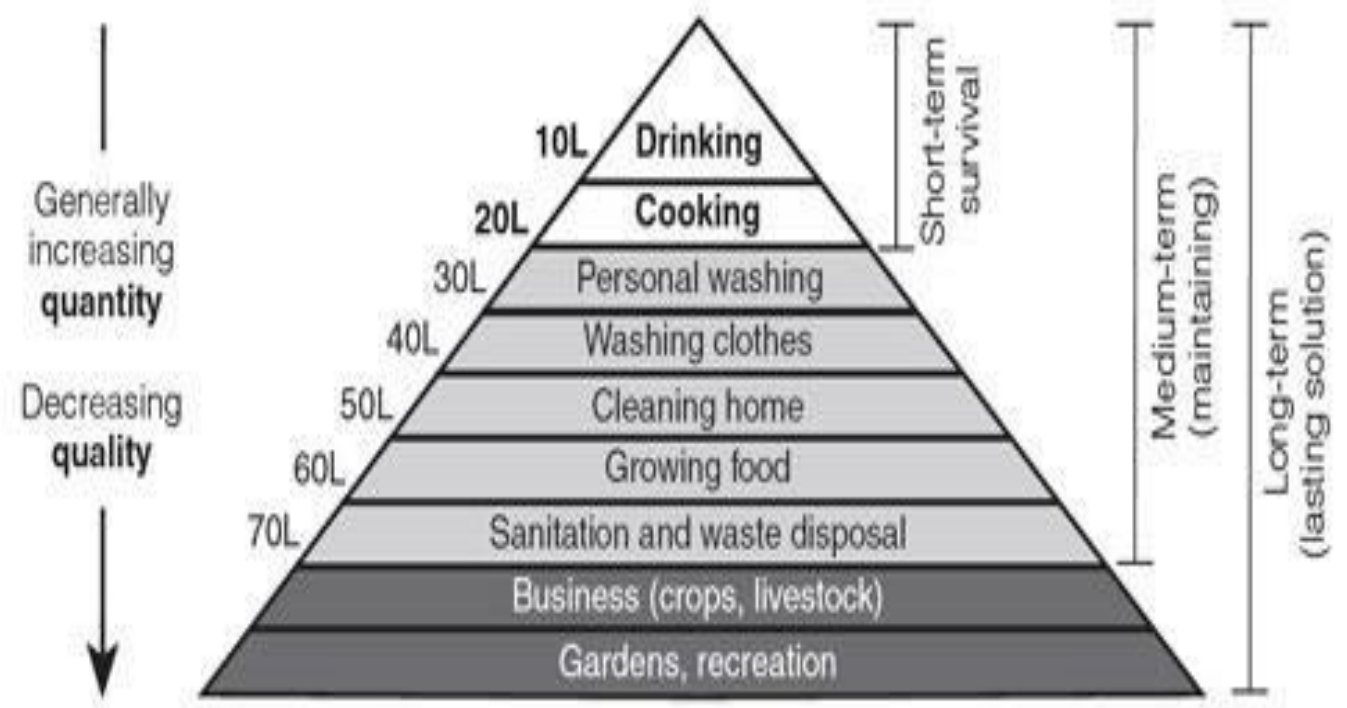

Figure 15. Hierarchy of water requirements (after Maslow's hierarchy of needs) 
Results of Analysis for Physicochemical Parameters

Table 5.4. Mean Physicochemical Results of water samples in study area

\begin{tabular}{|c|c|c|c|c|c|c|c|c|c|c|c|}
\hline & $\begin{array}{c}\text { UMU- } \\
\text { ELED } \\
\text { I } \\
\text { BH }\end{array}$ & $\begin{array}{c}\text { UMUOVO } \\
\text { BH }\end{array}$ & $\begin{array}{c}\text { UMUECHOK } \\
\text { WU } \\
\text { BH }\end{array}$ & $\begin{array}{c}\text { UMU } \\
\text { O- } \\
\text { BUTU } \\
\text { BH }\end{array}$ & $\begin{array}{c}\text { OYIV } \\
\text { O } \\
\text { STRE } \\
\text { A } \\
\text { M }\end{array}$ & $\begin{array}{c}\text { IYI } \\
\text { OKWU } \\
\text { STREA } \\
\text { M }\end{array}$ & $\begin{array}{l}\text { OGBA- } \\
\text { NELU } \\
\text { SPRING }\end{array}$ & $\begin{array}{c}\text { IYI } \\
\text { UMUO } \\
\text { VO } \\
\text { STREA } \\
\text { M }\end{array}$ & TANKER & $\begin{array}{c}\text { WHO } \\
\text { STANDA } \\
\text { RD }\end{array}$ & $\begin{array}{c}\text { REMA } \\
\text { RK }\end{array}$ \\
\hline pH & 4.98 & 5.0 & 4.9 & 4.95 & 4.9 & 5.0 & 5.15 & 5.1 & 5.14 & $6.5-7.5$ & Aci-dic \\
\hline $\begin{array}{l}\text { Turbid } \\
\text { ity }\end{array}$ & & & & & & & & & & & ok \\
\hline $\begin{array}{l}\text { Tempe- } \\
\text { rature }\end{array}$ & 25.68 & 0.126 & 25.72 & 0.135 & $\begin{array}{l}0.233 \\
25.0\end{array}$ & $\begin{array}{r}0.3 \\
25.5\end{array}$ & $\begin{array}{r}0.39 \\
26.96\end{array}$ & $\begin{array}{r}0.47 \\
24\end{array}$ & $\begin{array}{r}0.88 \\
29.88\end{array}$ & $\begin{array}{c}5 \text { NTU } \\
-\end{array}$ & ok \\
\hline $\begin{array}{c}\text { Hard- } \\
\text { ness }\end{array}$ & 3.74 & 3.92 & 3.61 & 4.026 & 5.78 & 6.11 & 5.28 & 5.86 & 3.76 & $200 \mathrm{mg} / \mathrm{l}$ & ok \\
\hline $\begin{array}{l}\text { Condu } \\
\text { c- } \\
\text { tivity }\end{array}$ & 50.83 & 51.9 & 56.7 & 52.5 & 34.1 & 35.5 & 36.2 & 35.9 & 17.7 & - & ok \\
\hline TDS & 33.24 & 33.95 & 36.9 & 33.5 & 23.08 & 23 & 23.4 & 23.088 & 11.5 & $500 \mathrm{mg} / \mathrm{l}$ & ok \\
\hline Salinity & 24.35 & 25.06 & 23.3 & 22 & 14.4 & 13.2 & 16.28 & 14.4 & 8.61 & $250 \mathrm{mg} / \mathrm{l}$ & ok \\
\hline DO & 14.33 & 14.08 & 11.33 & 10.1 & 6.717 & 6.21 & 8.71 & 6.71 & 7 & - & ok \\
\hline Iron & 0.08 & 0.086 & 0.086 & 0.06 & 0.1 & 0.098 & 0.09 & 0.098 & 0.115 & $0.1 \mathrm{mg} / \mathrm{l}$ & ok \\
\hline $\begin{array}{c}\text { Manga } \\
\mathbf{n} \\
\text { ese }\end{array}$ & 0.031 & 0.05 & 0.04 & 0.036 & 0.048 & 0.043 & 0.03 & 0.046 & 0.06 & 0.05 mg/l & ok \\
\hline $\begin{array}{l}\text { Chrom } \\
\text { i } \\
\text { um }\end{array}$ & 0.035 & 0.018 & 0.019 & 0.021 & 0.022 & 0.017 & 0.017 & 0.018 & 0.014 & $0.05 \mathrm{mg} / \mathrm{l}$ & ok \\
\hline $\begin{array}{c}\text { Sulpha } \\
\text { te }\end{array}$ & 0.21 & 2.26 & 2.05 & 2.28 & 2 & 1.1 & 2.18 & 1.61 & 2.58 & 200 mg/l & ok \\
\hline Copper & 0.03 & 0.0316 & 0.033 & 0.028 & $\begin{array}{c}0.031 \\
6\end{array}$ & 0.031 & 0.04 & 0.03 & 0.0316 & 0.05 & ok \\
\hline Colour & 5 & 5 & 5 & 5 & 5 & 5 & 5 & 5 & 5 & $15 \mathrm{NTU}$ & ok \\
\hline $\begin{array}{c}\text { Chlori } \\
\text { de } \\
\text { Total }\end{array}$ & 10.02 & 10.02 & 10.85 & 10.13 & 8.89 & 9.53 & 9.53 & 9.418 & 8.106 & $250 \mathrm{mg} / \mathrm{l}$ & ok \\
\hline $\begin{array}{l}\text { Alkalin } \\
\text { ity }\end{array}$ & 0.053 & 0.052 & 0.05 & 0.049 & 0.051 & 0.0517 & 0.051 & 0.05 & 0.051 & - & ok \\
\hline Zinc & 0.88 & 0.98 & 0.88 & 0.866 & 1.08 & 1 & 0.86 & 1 & 0.766 & $5 \mathrm{mg} / \mathrm{l}$ & ok \\
\hline $\begin{array}{l}\text { Nitrate } \\
\text { Total }\end{array}$ & BDL & BDL & BDL & BDL & BDL & BDL & BDL & BDL & BDL & $10 \mathrm{mg} / \mathrm{l}$ & ok \\
\hline $\begin{array}{c}\text { colifor } \\
\mathbf{m}\end{array}$ & 8 & 0 & 0 & 8 & 1 & 0 & 0 & 1 & 4 & 0 & Not ok \\
\hline $\begin{array}{l}\text { Taste/ } \\
\text { Odour } \\
\end{array}$ & $\begin{array}{c}\text { Unobj } \\
\text { ect - } \\
\text { ionabl } \\
\mathrm{e} \\
\end{array}$ & $\begin{array}{c}\text { Unobjection } \\
\text { able }\end{array}$ & $\begin{array}{c}\text { Unobjectionab } \\
\text { le }\end{array}$ & $\begin{array}{c}\text { Unobj } \\
\text { ect - } \\
\text { ionabl } \\
\mathrm{e} \\
\end{array}$ & $\begin{array}{c}\text { Unobj } \\
\text { ec } \\
\text { tionab } \\
\text { le } \\
\end{array}$ & $\begin{array}{c}\text { Unobjection } \\
\text { able }\end{array}$ & $\begin{array}{c}\text { Unobjetion } \\
\text { able }\end{array}$ & $\begin{array}{l}\text { Unobjec } \\
\text { tio nable }\end{array}$ & $\begin{array}{c}\text { Unobjetion } \\
\text { able }\end{array}$ & $\begin{array}{c}\text { Unobjecti } \\
\text { onable }\end{array}$ & ok \\
\hline
\end{tabular}

From the results of the physico-chemical analysis, all the sources of water supply appear to conform to international guidelines on water quality except the microbial analysis of waters aples fron the straems and commercial water tankers where the coliform count indicates contamination.

\section{CONCLUSION AND RECOMMENDATIONS}

The present water supply situation in the study area is extremely poor. Inhabitants get far less than the required per capita water supply. The little they get is of doubtful quality. Fortunately the area is underlain by very aquiferous formations capable of providing enough water for the populace. High rainfall in the area is expected to provide enough recharge for the aquifers. The superficial cover of permeable fine sands is expected to enhance the infiltration of precipitation. Existing surface water bodies within the study area are difficult to access, of insufficient quantity and hence liable to seasonal failure. Where possible, conjuctive use of the various sources should be adopted to maximise the relative advantages of 
each source. The prospects of Imo River and its tributaries could provide sources of domestic water supply in Old Umuahia can be studied with possible construction of an earth dam in mind.

\section{REFERENCES}

[1].Abii ,T. A., \& Nwabienvanne E.U, (2007). Investigation on Trace Metals Content of some Selected Borehole Water around Umuahia Metroplolis. Research Journal of Applied Sciences, 2(4), 494-497.

[2].Chukwu, G.U. (2008). Water Quality Assessment of Boreholes in Umuahia South Local Government Area of Abia State, Nigeria. The Pacific Journal of Science and Technology. 9(2), 592 - 598.

[3].Ebilah-Salmon and Partners, (1994). Investigation of the Existing Water Supply Facilities Within the University Complex, Geophysical Report and Recommendations for Reactivation and Future Exploitation for Potable Water Supply. Federal University of Agriculature, Umudike. pp25

[4].Efe S.I, (2006). Quality of Rainwater Harvesting for Rural Communities of Delta State, Nigeria Journal of the Environment, 26(3), 175 -181.

[5].Ekpebegh, U. N. (2015). An Evalaution of Water Supply Alternatives in Old Umuahia, Abia State, Nigeria. Unpublished MPhil Dissertation, Institute of Geosciences and Space Technology (IGST), Rivers State University of Science and Technology, Port Harcourt. 98pp.

[6].Mbonu, P.D.C., Ebeniro J.O., Ofoegbu C.O. and Ekine A.S, (1991). Geoelectric Sounding for the Determination of Aquifer Characteristics in Parts of Umuahia Area of Nigeria. Geophisics, 56, 284-291.

[7].Igboekwe M.U., Okwueze E.E., \& Okereke C.S. (2006). Delineation of natural aquifer zones from goelectric sounding in Kwa Ibo river watershed, south Eastern Nigeria. Journal for Engineering and Applied Science, 1 (4), 410 -421 .

[8].Ijeh, B. I., \& Udoinyang I.E. (2013). Assessment of the Groundwater Quality in Parts of Imo River Basin, Southeastern Nigeria: The Case of Imo Shale and Ameki Formations. Journal of Water Resource and Protection,.5, 715-722.

[9].Ijeh, B. I. (2013). Determination of the Vulnerability of Water Supply Aquifers in Parts of Imo River Basin, SouthEastern Nigeria: The Case of Benin Formation. International Journal of Modern Engineering Researc, 3(1),291-295.

[10]. Johnson A.I. (1967). Specific Yields - Compilation of Specific Yields of Various Materials: U.S. Geological Survey Water Supply Paper 1662 (D),104-111

[11]. Nkwocha E. E. (2008) Water Supply Deficiency and Implications for Rural Development in the Niger-Delta Region of Nigeria. Social Indicators Research, 90(3), 409-418

[12]. Onwuegbuche, A. A., (1993); Geoelectrical Investigations in the Imo River Basin Nigeria. Unpublished Ph.D thesis. Department of Physics, University of Calabar. pp.2-62.

[13]. Ukandu1 J. S., Udom G. J., Nwankwoala H. O. (2011). Hydrochemistry of Groundwater in Umuahia South Local Government Area, Abia State, Nigeria. British Journal of Applied Science \& Technology, 1(4),141-151.

[14]. Uma K. O and Egboka B. C. E. (1988). Problems Of Rural Water Supplies In A Developing Economy: Case Studies Of Anambra and Imo States of Nigeria. Water International, 13 (1), 33 - 45. 